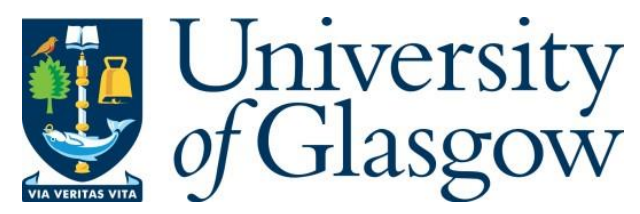

Steel, C. (2017) Speech without limits: defining informality in Republican Oratory. In: Papaioannou, S., Serafim, A. and Da Vela, B. (eds.) The Theatre of Justice: Aspects of Performance in Greco-Roman Oratory and Rhetoric. Series: Mnemosyne supplements, monographs on Grek and Latin language and literature (403). Brill: Leiden, pp. 75-89. ISBN 9789004334649.

There may be differences between this version and the published version. You are advised to consult the publisher's version if you wish to cite from it.

http://eprints.gla.ac.uk/140071/

Deposited on: 24 April 2017

Enlighten - Research publications by members of the University of Glasgow http://eprints.gla.ac.uk 


\section{SPEECH WITHOUT LIMITS: DEFINING INFORMALITY IN REPUBLICAN ORATORY ${ }^{1}$}

\section{CATHERINE STEEL}

\section{Introduction}

The dramatic nature of Roman forensic activity is well-attested. ${ }^{2}$ Cicero's practice shows how extensively dramatic plots, characters and language could be used in court when the circumstances of a case made them strategically advantageous; and his theoretical works, and those of his successors, demonstrate the close links which could be drawn between oratorical delivery and the technical framework of acting. Research on the dramatic aspects of Roman oratory has tended to concentrate on the orator himself, the speeches which he delivered and his gestures and manner of speaking. To this extent, it has bought into the fiction, so carefully created in the surviving texts of oratory that forensic speech is under the control of the speaker. But the impression of Roman court practice given by Cicero's surviving forensic speeches is profoundly misleading. They offer a single unbroken text, in which the orator speaks without interruption for one often very considerable period of time. Reality was very different. Orators built their cases from a combination of their own words and those elicited from the witnesses they summoned. They drew on the presence of the defendant and his supporters, even if the defendant did not in fact speak. And they were faced by the responses of the audiences, both the formal constituted jury who would judge the case, and those who chose to listen by standing within earshot of the court proceedings.

In this chapter, I explore the informal exchanges that took place within and around Republican courts. Through the term 'informal' I seek to bring together a range of occasions which are connected to, but distinct from, the orator's prepared words in the form of a continuous speech. Some of these exchanges, such as those with defendant and witnesses, were integral to court practice, and consequently could be prepared for and, to a certain extent, managed. Others were much more unpredictable: a corona of listeners who had no formal involvement with the court could be expected, but not guaranteed. Orators needed to manage

\footnotetext{
1 This chapter arises from research conducted during the European Research Council funded project The Fragments of Republican Roman Oratory. I am grateful to Andreas Serafim, Sophia Papaioannou and Beatrice da Vela for their invitation to contribute to this volume.

${ }^{2}$ Geffcken (1973); Axer (1980); Harries (2007) 129-47; Bablitz (2007).
} 
all these elements in a forensic case, since they had the potential to affect the outcome; but since they involved words exchanged with other people, not all of them benevolent, things could happen in ways other than the orator hoped or expected. As a result, they showcased an orator's ability to improvise. The connections between forensic oratory and public oratory more widely in Republican Rome can be seen in such informal exchanges and improvisatory capacity: in the second part of this chapter, I explore other venues for oratory, especially the contio, and the ways in which such venues set orators challenges in engaging in an unscripted and unprepared manner with their audience. The close relationship between forensic activity and the wider political context meant that there was a continuum of skills and dangers: forensic activity provided one among a number of locations for members of the elite to engage with the citizen body, and such engagement could go badly as well as successfully. ${ }^{3}$

\section{Quaestiones}

Cases, for both prosecution and defence, were built up from a combination of the orator's own presentation of the case and of evidence provided by witnesses, in statements and in subsequent cross-examination. ${ }^{4}$ The precise balance between speech and witness evidence and the order in which both elements were presented varied between different courts and was subject to variation over time as the procedural framework of the quaestiones perpetuae was modified, but the importance of contributions from witnesses was a constant, as the attention paid to the handling of witness evidence in rhetorical texts demonstrates. ${ }^{5}$ Their words, whether spoken or written, were a major and indispensable contribution to the construction of a speech's argument. ${ }^{6}$ Forensic advocacy needed witnesses. But witnesses were also unpredictable. Their statements could be and surely were very carefully prepared, but their performance in court could not be guaranteed. ${ }^{7}$ Moreover, the other side would call witnesses, and cross-examination of hostile witnesses engendered a fresh set of dangers. In De Oratore the treatment of invention concludes (2.294-306) with a discussion of how an orator must seek above all not to do harm to his case, for letting that happen is, according to Crassus (as relayed through Caesar Strabo), the mark of someone "wicked and treacherous" (297). ${ }^{8}$ Antonius does not fundamentally

\footnotetext{
3 The focus in this chapter is on the quaestiones: other law cases generally offered much less scope and requirement for the kind of exchange I here explore, since they were normally of much less public interest.

${ }^{4}$ On witnesses in Roman forensic practice during the Republic: David (1992) 422-8; Lévy (1992) 23-33; Steck (2006); Guérin (2015).

${ }^{5}$ E.g. Rhet. ad Her. 2.9-10; Cic. De Orat. 2.118-9.

${ }^{6}$ Butler (2002).

${ }^{7}$ Guérin (2015) notes that there is little evidence for any barriers to witness coaching at Rome.

${ }^{8}$ Cic. De Orat. 2.297: illud uero improbi esse hominis et perfidiosi.
} 
disagree, but takes Crassus to task for implying that only a depraved advocate would allow this to happen:

etenim permulta sunt in causis in omni parte orationis circumspicienda, ne quid offendas, ne quo inruas: saepe aliqui testis aut non laedit aut minus laedit, nisi lacessatur; orat reus urgent aduocati, ut inuehamur, ut male dicamus, denique ut interrogemus: non moueor, non obtempero, non satis facio: neque tamen ullam adsequor laudem; homines enim imperiti facilius quod stulte dixeris reprehendere quam cum sapienter tacueris laudare possunt. hic quantum fit mali, si iratum, si non stultum, si non leuem testem laeseris! habet enim et uoluntatem nocendi in iracundia et uim in ingenio et pondus in uita. nec, si hoc Crassus non committit, ideo non multi et saepe committunt. quo quidem mihi turpius uideri nihil solet, quam quod ex oratoris dicto aliquo aut responso aut rogato sermo ille sequitur: 'occidit.' 'aduersariumne?' 'immo uero' aiunt 'se et eum, quem defendit.' hoc Crassus non putat nisi perfidia accidere posse; ego autem saepissime uideo in causis aliquid mali facere homines minime malos.

And so throughout a speech you must keep much under review so as not to run aground on a problem or rush into one: often a witness won't harm your case, or will do less harm if he isn't provoked; the defendant begs me and his supporters urge me to attack him, abuse him and cross-question him: I'm not moved, I don't comply, I don't do as they wish; and I get no praise for it; for men without experience can more easily criticise stupid things which have been said that praise things which wisely have not been said. What damage can be done if you harm an angry, sensible, serious witness! In his anger he is willing to damage you and his intellect gives him force and his way of life gives him weight. And even if Crassus doesn't do this, plenty do so, quite often. To me then, nothing is more shameful than when the response to something an orator has said, or replied or answer is this exchange: 'He's done for him' 'His opponent?' 'No, himself, and his client'. Crassus thinks this can only happen through treachery; but I very often see men who aren't at all bad doing bad things in court. ${ }^{9}$

The conversation is concerned with an advocate's capacity to damage his case in general, but it is striking that the handling of witnesses is used as the main example of a damaging (and

\footnotetext{
${ }^{9}$ De Orat. 2.301-3.
} 
unnecessary) action. The situation Antonius describes is that of cross-questioning a witness for the other side, and implies that there are circumstances - when the witness is credible because of his life and intellect - when no questioning, or at least no hostile questioning, is the best line to follow. There is a suggestion, too, that such refusal to engage vigorously with a hostile witness was likely to provoke criticism from the rest of the defence team.

Furthermore, what witnesses said could be believed, or not believed; and the judges' witholding of belief was a comment on both the orator who had brought the witness forward and on the witness him- or herself. When, as often was the case, the witness as well as the defendant was involved in the political life of Rome, the reaction to a witness' performance by the judges, composed of his peers, became an exercise of public judgement parallel to, if considerably less freighted than, the judgement delivered on the defendant himself. ${ }^{10}$ The anger which Antonius knew could be stirred up in a witness for the other side is a linked phenomenon: witnesses became angry in such circumstances because hostile cross-questioning was designed to undermine their credibility, with results that could potentially extend beyond the court itself. $^{11}$

A well-known example of this phenomenon arose from the witness evidence offered at Clodius' trial on sacrilege charges in 61. Cicero gave evidence which destroyed Clodius' alibi. But Clodius was still acquitted; unsurprising, then, that Cicero sought as soon as possible to reestablish his credibility by establishing bribery, not his fallibility, as the cause of the judges' decision. It is significant, too, that this act of interpretation took place in public, at a meeting of the Senate which took place soon after Clodius' acquittal: Cicero gave a speech at this meeting, in which he attacked Clodius, but he also exchanged remarks with Clodius in what he describes as an altercatio:

surgit pulchellus puer, obicit mihi me ad Baias fuisse; falsum sed tamen. 'quid? hoc simile est' inquam 'quasi in operto dicas fuisse?' 'quid' inquit 'homini Arpinati cum aquis calidis' 'narra' inquam 'patroni tuo, qui Arpinatis aquas concupiuit'; nosti enim Marianas. 'quousque' inquit 'hunc regem feremus?' 'regem appellas' inquam 'cum Rex tui mentionem nullam fecerit?'; ille autem Regis hereditatem spe deuorarat. 'domum' inquit 'emisti.' 'putes' inquam 'dicere “iudices emisti”.' 'iuranti' inquit ‘tibi non crediderunt.'

\footnotetext{
${ }^{10}$ Cases in which witness evidence provided by eminent men was disbelieved by the judges form the majority of cases which Valerius Maximus discusses in his section De testibus (8.5).

${ }^{11}$ See Rhet. ad Her. 2.9, where the two activities the orator needs to engage with in relation to witnesses are inprobatio, discrediting, and interrogatio, cross-examination; the two headings to be used for the former are way of life (uita) and the consistency of their evidence with other evidence (testimoniorum inconstantia).
} 
'mihi uero' inquam 'XXV iudices crediderunt, XXXI, quoniam nummos ante acceperunt, tibi nihil crediderunt.'. magnis clamoribus adflictus conticuit et concidit.

The pretty little boy get up and accuses me of being at Baiae; not true, but anyway. 'Well? Is that like saying that I was somewhere hidden?' 'What has a man from Arpinum to do with warm springs?'. 'Tell that', I said, 'to your counsel, who was keen on an Arpinum man's property at the springs' (you know about Marius' property.) 'How long', he said, 'shall we bear this king'? 'You appeal to a king, when Rex made no mention of you?' (he had been hoping to squander an inheritance from Rex). 'You bought a house'. 'You would think', I said, 'that he said, "He bought a jury". 'They didn't believe you on oath'. 'Oh twenty-five judges did, but thirty-one gave you no credit at all - they took their fee upfront'. Overwhelmed by a great roar he falls silent and collapses. ${ }^{12}$

It was not enough for Cicero to state that Clodius was guilty; he had to overwrite the verdict with a fresh interaction with Clodius in which he now came out victorious, as indicated by the response of this fresh audience, whose shouts, Cicero claimed, showed their support for him and his presentation of Clodius as one acquitted through bribery.

The defendant could be brought forward as a witness, and he could also speak in his own defence. ${ }^{13}$ Even if he (or she) were silent, his presence in the court created opportunities for both prosecution and defence orators. He and his reactions could be used as a physical exemplar to support the orator's argument, and the defendant's capacity to evoke pathos is amply evidenced from the perorations of Cicero's speeches, where his presence, and his tears, are demonstrations of the need to acquit, both through his manifestation of virtue and through a contrast with his prospective absence were he to be removed from the res publica by the decision of the judges. ${ }^{14}$ In such passage, Cicero can put words into his silent client's mouth: so Murena orat atque obtestat the judges (Mur. 87). Milo offers a variation on this model. Cicero appeals to the judges not to misread the signs:

nolite, si in nostro omnium fletu nullam lacrimam aspexistis Milonis, si uoltum semper eundem, si uocem, si orationem stabilem ac non mutatam uidetis, hoc minus ei parcere: haud scio an multo etiam sit adiuuandus magis.

\footnotetext{
${ }^{12}$ Cic. Att. 1.16.10;

${ }^{13}$ Steck (2006) 120-8.

${ }^{14}$ So, for example, Mur. 86-90; Flac. 101-6; Sest. 144-7; Cael. 77-80; also: Winterbottom (2004) 215-30.
} 
Do not feel less compassion towards Milo if, in the midst of all our tears, you see none from him, if his expression is unchanging, if his voice and speech are firm and unaltered: perhaps these should rather help him. ${ }^{15}$

Milo does not engage in the expected gestures and behaviour of the defendant facing an imminent verdict, and we may suspect that it is this failure which forced Cicero to note and draw attention to the gap in order to redefine it in terms of Milo's heroism. But the passage neatly pinpoints the conventions of defendant behaviour. The distinctive clothes which defendants were expected to assume and lack of care for aspects of their physical appearance also contributed to their distinctive presence in court, and were also conventions whose neglect created a negative impression. The defendant's value was not confined to the emotional charge of his potential conviction: his physical presence could also become a guarantee of his moral virtues.

A very striking example of this phenomenon is Antonius' defence of Manius Aquillius early in the $1^{\text {st }}$ century B.C., at which he ripped open Aquillius' tunic open to display his scars, all at the front and thus indicators of his courage in hand to hand combat. ${ }^{16}$ Above all, the defendant needed to stay the course. Cicero records the earlier trial of one of Oppianicus' alleged co-conspirators in Pro Cluentio (58-9): he structures the anecdote around the punchline of the defence advocate repeatedly urging the judges to 'look!' at the defendant, only to turn himself and find his client gone. But while Fabricius' departure was as a result funny, it also signalled his despair in his own case. Unsurprisingly, he was convicted.

In this group of verbal and non-verbal behaviours, the defendant was often not alone. Cicero's speeches record the presence of children (whose vulnerability if deprived of their male parent is emphasised for pathetic effect), siblings and parents. ${ }^{17}$ Valerius Maximus records cases where a defendant who was generally regarded as guilty escaped conviction because of the feelings his relatives engendered among the judges. Thus A. Gabinius escaped conviction in 54 when prosecuted by Memmius because his son "under the influence of total panic threw himself as a suppliant at Memmius' feet". ${ }^{18}$ But Quintilian adds a note of caution: he has a

\footnotetext{
${ }^{15}$ Cic. Mil. 92.

${ }^{16}$ Cic. De Orat. 2.124, 2.194-5; cf. also: Cic. Verr. 2.5.3; Flacc 98; Liv. Per. 70; Quint. I.O. 2.15.7.

${ }^{17}$ According to Cicero's subsequent written presentation of the cases, Sulla, Flaccus and Sestius had their children present (Sull. 88; Flacc. 106 Sest. 144, 146); Caelius and Fonteius their parents (Cael. 79; Font. 48); Fonteius, a sibling (Font. 46-49).

${ }^{18}$ Val. Max. 8.1 absol. 3: consternationis impulsu ad pedes se Memmii supplex prostrauit.
} 
dossier of peroration mishaps which occurred because of a failure on the part of the defendant and his supporters to back up what the orator was saying. ${ }^{19}$ Quintilian draws on his own forensic experience but he also has examples from the Republican period. He notes that disaster is particularly likely to happen when there has been a striving for dramatic effect: praecipue uero cum aliqua uelut scaenice fiunt aliter cadunt. ${ }^{20}$

Forensic oratory thus involved the orchestration, by the orator, of his own formal extended speech with a range of supporting material, some of it verbal, some not, but all arising from his interaction with other individuals, present and absent. ${ }^{21}$ This supporting material was an integral part of forensic practice: neither prosecution nor defence could succeed without evidence from witnesses and only when the defendant was speaking on his own behalf without colleagues can we envisage a speech without interaction between orator and defendant - and even in such a hypothetical case, the defendant might choose to appeal to members of his family. An effective orator had to prepare this material as carefully as he could but be ready to change tack when faced with something unexpected, whether that be what witnesses for the other side said or the recalcitrant behaviour of those he had organised for his own side. Cicero's speeches provide metatextual indicators, such as deictic pronouns or instructions to court officials to read material out, which demonstrate how he used this kind of material, even though their actual deployment will surely have disrupted the flow of his speech as it is preserved in the versions he disseminated.

Interaction with witnesses, clients and clients' entourages do not, however, exhaust the possibilities for informal exchange in the Republican court. The orator had also to relate to his audience, or better audiences: a clear distinction can be drawn between the judges and court president on the one hand, and everyone else who might be listening. The first group had no choice about their presence, and were directly obliged to participate in the process by recording their vote at its end. The second group, which can be described as an "informal audience", was the corona, composed of any individual who wished to stand in the vicinity of the court and watch and listen. Such individuals were under no obligation to arrive at the start of proceedings nor to stay until the end and had no formal way of registering their opinion on what they heard.

Interactions between orators and these audiences were a normal part of what happened in court. To a certain extent, they can be traced in Cicero's speeches, most obviously in the

\footnotetext{
${ }^{19}$ Quint. I.O. 6.1.37-49.

${ }^{20}$ Quint. I.O. 6.1.38, things which are designed for dramatic effect particularly go wrong.

${ }^{21}$ Witness testimony could be provided in written form: Butler (2002); Steck (2006) 58. Such testimony was insulated from the unpredictability inherent in the other situations I discuss.
} 
frequent appeals to iudices and to a lesser extent in the creation of a shared forensic history drawing on a collective identity for the judges in the quaestiones. ${ }^{22}$ Revealingly, in the discussion of wit and humour in De Oratore, Caesar Strabo early on identifies as faulty uses of humour to attack the other side which could be transferred to judges. ${ }^{23}$ Orators will have hoped, at least, for attention from the judges, and to avoid evoking their hostile laughter, and judges were obliged, in theory at least, to remain in court. But no speaker was guaranteed the attention of the corona: it had the capacity to form and disperse at will, and its presence and size could be taken as a marker of a speaker's quality, or at least of his ability to command attention. For the character 'Brutus' in Brutus, the corona is a sine qua non for forensic oratory: ego uero...ut me tibi indicem, in eis etiam causis, in quibus omnis res nobis cum iudicibus est, non cum populo, tamen si a corona relictus sim, non queam dicere. ${ }^{24}$ His observation is provoked by the famous incident involved the elder Curio, who was abandoned by his audience at a contio. ${ }^{25}$ We may suspect a certain degree of pointed characterisation in this passage, with Brutus deliberately chosen to articulate the link between mass participation and good oratory in the strongest possible terms in keeping with his role in the dialogue to exemplify what has been lost to oratory with the transformation in political practice after the civil war. There may in fact have been significant differences between different kinds of forensic case in levels of coronal participation, with some (those with well-known defendants and/or lurid charges) attracting considerably more public interest than others. Nonetheless, the fundamental point is convincing: a voluntary audience was a sign of oratorical skill, and thus to be cherished. This attitude was not undermined by a lack of inhibition among members of the corona in their response to what they heard and saw. Indeed, positive signs of approbation were welcomed. One of Catullus' poems record a forensic performance by his friend Calvus:

risi nescio quem modo e corona

qui, cum mirifice Vatiniana

meus crimina Caluos explicasset,

admirans ait haec manusque tollens

\footnotetext{
${ }^{22}$ This is particularly evident as a tactic in the Verrines (in which the composition of juries is a live issue) and in Pro Cluentio, which engages closely with recent judicial decisions.

${ }^{23}$ Cic. De Orat. 2.245.

${ }^{24}$ Cic. Brut. 192: "for myself, at least, even in cases where our whole business is with the judges, not the people, I cannot speak if I am deserted by the corona".

${ }^{25}$ Cic. Brut. 192, 305; also: Rosillo Lopez (2013) 294-5.
} 
'di magni, salaputium disertum!'26

As the meaning of salaputium is unclear exactly what made Catullus laugh is obscure, but the remark was clearly meant as a compliment to the speaker, and one uttered sufficiently loudly for at least some of the other members of the corona to hear. ${ }^{27} \mathrm{We}$ can contrast the passage from De Oratore quoted above (301-3), where Antonius' incontrovertible evidence for a failed forensic strategy is a sermo, a conversation: he does not identify where the conversation is taking place but the only relevant location is surely among members of the corona. As the judges could see, and hear, the reactions of the corona just as much as the orators could, a bad response was not simply upsetting to an orator; it could directly influence the ultimate verdict. In Antonius' description of his great triumph at the Norbanus case, it is the moment at which he realises me in possessionem iudici ac defensionis meae constitisse, quod et populi beneuolentiam mihi conciliaram, cuius ius etiam cum seditionis coniunctione defenderam, et iudicum animos totos uel calamitate ciuitatis uel luctu ac desiderio propinquorum uel odio proprio in Caepionem ad causam nostram conuerteram, tum... that marks his transition the most emotionally charged part of his speech. ${ }^{28}$ It is not simply the attitude of the judges which is relevant; having the people - by which Antonius must mean those whose opinion he could gauge, namely those present around the court in the corona - on his side was also crucial. The corona mattered. Its reactions to the case being heard were available to the judges, and contributed to their decision; a competent orator had at the least to try to prevent it from behaving in a way that prejudiced his case, and ideally to deploy it as a factor in his favour.

Effective forensic performance thus required the orator to manage and respond to a great many elements, not all of which were under his direct control. These had the potential to blur the distinction between formal and informal speech and between prepared and unprepared speech. Indeed, one function of a written version of a speech was to sanitise what had actually happened in court and, if necessary, to impose upon a messy and unsatisfactory set of exchanges the appearance of order and control. A clear example is Cicero's In Vatinium, which offers as a continuous text the record of what would in court have involved cross-examination

\footnotetext{
${ }^{26}$ Cat. Carm. 53: "I laughed at someone from the corona who, when my Calvus was unrolling the Vatinian chargesheet wonderfully, said in wonder, lifting up his hands, 'Good heavens, what an eloquent salaputium!'”.

${ }^{27}$ Corbeill (1996) 39; on the meaning of salaputium and possible stylistic implications: Weiss (1996) 353-9; Hawkins (2012) 329-53.

${ }^{28}$ Cic. De Orat. 2.200: "that I had taken possession of the court and my defence, because I had won over the people's good-will, whose rights I had defended in connection with the disturbance, and I brought over to our side all the judges' opinions, either because of the crisis facing the community or through grief and longing for their relatives or specific distaste for Caepio, then..."
} 
as part of the trial of Sestius. ${ }^{29}$ Cicero records in a letter to Quintus the result of the trial, including its effect on Vatinius: ...Vatinium...arbitratu nostro concidimus dis hominibus plaudentibus. ${ }^{30}$ The speech itself, a pendant to the extraordinarily ambitious Pro Sestio, was designed to confirm that victory in permanent form.

\section{Other venues for oratory}

The interrelationship of formal speech with informal exchanges in forensic contexts show marked similarities to what happened during certain kinds of deliberative speech during the late Republic. Speeches delivered to the people at contiones were also liable to interruption, both predictable and not, and the contio itself could be used to enact an oral exchange to which the audience might respond, just as the corona could choose to offer a reaction to the performance it viewed. The similarities are surely not coincidental. Quaestiones perpetuae, which met regularly to hear a particular charge and at which the decision was taken by members of a small subset of the citizen body, were a relatively recent development in Roman legal practice. The first was established in 149 B.C., to hear cases of extortion (repetundae); the development of other quaestiones cannot be established with complete chronological precision but it does appear that they were only systematised as a set of fully parallel courts by Sulla very shortly before Cicero made his debut before a quaestio with his defence of Roscius Amerinus in 80 B.C. ${ }^{31}$ Prior to the establishment of the quaestiones, capital offences were judged by the people, and they retained that capacity throughout the Republic, even if it was almost always delegated to quaestiones.

On one striking occasion it was not and the people resumed their role as capital judges, when Labienus prosecuted C. Rabirius in 63 B.C. on a charge of perduellio. ${ }^{32}$ The conceptual as well as physical space in which the people acted as judges remained open throughout the Republic; and once quaestiones had been created the assertion by the people of direct rather than indirect judgement became a move with strong popularis colouring. It can be connected to demands for accountability from magistrates, as appears to be the case with special quaestiones set up in the later $2^{\text {nd }}$ century, to investigate unchaste behaviour by Vestal Virgins

\footnotetext{
${ }^{29}$ Pocock (1926); Bensi (2009) 427-58; Corbeill (1996) 49-55.

${ }^{30}$ Cic. Qfr. 2.1.1, we cut up Vatinius at our pleasure, to great applause from gods and men. Divine approval presumably involved some meteorological or avian phenomenon. Cicero notes later in the letter that Vatinius left the court 'upset and damaged' (perturbatus debilitatusque) but his speech was not the only cause: a prosecution against Vatinius had been promised by others present.

${ }^{31}$ Lintott (2004) 61-78.

${ }^{32}$ Lintott (2008) 120-5.
} 
and misconduct by magistrates in connection with the war with Jugurtha. ${ }^{33}$ The policing of behaviour which affected the res publica was a matter for all citizens. ${ }^{34}$ Their oversight was, by the end of the Republic, largely delegated to the quaestiones perpetuae, but control could be reasserted.

It is in this sense, that of the intimate connection between the well-being of the res publica and the behaviour of its magistrates, that the quaestiones were political. The offences they considered were committable most easily, or in cases only, by magistrates and those seeking such office; as a result, the verdicts had political significance. This remains the case even if, as Riggsby has argued, what we know of jury deliberations indicates that judges reached their decision, and were expected so to do, on the basis of the evidence in front of them and not as the result of pre-existing support or hostility towards the defendant, however that might have been engendered. ${ }^{35}$ Trials at quaestiones were political because of their content, and consequently the identity of defendants; but they were probably not, or only very rarely, political in the sense that animosities and oppositions developed elsewhere in the public sphere found articulation in the votes cast by judges.

The inherently political nature of forensic quaestiones, and their development out of a situation in which the people judged, helps to explain the similarities between aspects of forensic performance into other areas of public life. There was an annual process of judgement - though not in a forensic context, nor with a specific focus on wrong-doing - in Roman elections, where the people reached a collective decision about the identity of those they wished to serve them as magistrates. In contrast with other aspects of Roman public life, formal oratory did not play a role in the process of elections; but other kinds of speech could not be similarly controlled. ${ }^{36}$ Failure to respond appropriately or adequately to informal challenge, query or observation by the electorate could prejudice a candidate's chance to win. Such exchanges became part of the persona a candidate presented and the narrative which he offered; facility in managing them, insofar as they were amenable to management, was a useful skill. Cicero gives a revealing portrait of the expectations of a candidate in his defence of Plancius on charges of electoral bribery, and Valerius Maximus has an entire section devoted to electoral defeats which indicate the pitfalls attached to inappropriate interaction with the people, whether

\footnotetext{
33 Vestal Virgins: 113, quaestio presided over L. Cassius Longinus Ravilla; Jugurthine war, quaestio extraordinaria established by a lex Mamilia in 109; also: Rawson (1974) 207-9.

${ }^{34}$ Riggsby (1999) 157-71.

${ }^{35}$ Riggsby (1999) 5-20.

36 Tatum (2013) 133-50.
} 
it be ill-judged humour, as in the case of Scipio Nasica, or stinginess, as with Aelius Tubero. ${ }^{37}$ Cicero himself capitalised on the opportunities offered by oratory in the Senate during his consular campaign by disseminating In Toga Candida. ${ }^{38}$ Although fragmentary and preserved largely in Asconius' commentary, it is clear that the speech, though ostensibly a contribution to a debate on ambitus legislation, was a personal attack on his two most serious competitors, Antonius and Catilina. According to Asconius, Antonius and Catilina replied in kind. ${ }^{39}$ Thus a senatorial debate was hijacked by consular candidates, seeking to impress their senatorial peers with their suitability for office and - more importantly - the weaknesses of their rivals.

Another important arena for public judgement was the census and its reviews of the senatorial and equestrian orders. During this process, an individual's identity as a senator or a member of the equestrian class could come to an end; although the consequences were not remotely as severe as conviction on a capital charge, such a result was a reputational disaster. Senators who managed to reverse the censors' decision by regaining their membership of the Senate were figures of exemplary interest. ${ }^{40}$ The people had never had oversight of the census, but at the very end of the Republic Clodius sponsored a law during his tribunate which gave those expelled or otherwise rebuked by the censors the right to a hearing. ${ }^{41}$ This measure is clearly in a popularis tradition of demanding accountability for magistrate's actions: the censors could no longer reach arbitrary decisions about senatorial membership. As it happens, Valerius Maximus refers to an incident at a hearing in front of the only censors to be affected by this lex Clodia, Valerius Mesalla and Servilius Isauricus in 55 or 54 B.C. ${ }^{42}$ Scribonius Libo was being accused in front of the censors by Helvius Mancia; Pompeius Magnus, who was apparently present in some capacity to support Libo, commented unfavourably on Mancia's age, who responded with an attack on Pompeius' own career as a young man. What exactly Valerius Maximus is quoting is something of a problem when he claims to reproduce what Mancia said, but even if it is not Mancia's own text, the occasion itself is revealing. Within what seems to have been a quasi-forensic context, perhaps when Pompeius was offering

\footnotetext{
${ }^{37}$ Cic. Planc.; Val. Max., 5.7, De Repulsis; also: Cicero's observation on the exemplum of Tubero at Mur. 76: odit populus Romanus priuatam luxuriam, publicam magnificentiam diligit.

${ }^{38}$ Crawford (1994) 163-203.

${ }^{39}$ Asc. 93-94C.

40 The two most striking cases are perhaps Licinius Geta, on whom see Wiseman (2009) 33-57, and Cornelius Sura, consul in 71 and executed in 63. They lost senatorial membership in the two most expulsive censuses of the late Republic, in 115 and 70.

${ }^{41}$ Tatum (1999) 133-5.

${ }^{42}$ Val. Max. 6.2.8; these censors did not complete the lustrum. This lex Clodia was repealed in 52 B.C.
} 
testimony, an unscripted, unplanned oral exchange took place, in which Pompeius suffered reputational damage through his inability to control and dominate impromptu interactions. ${ }^{43}$

\section{Conclusions}

Public speech mattered hugely in Republican Rome, but it was not a phenomenon confined to formal oratory. It was not simply that the audience always had the opportunity to comment, to respond and to express their opinion on hearing a speech, (even though the precise form in which that response might emerge varied between kinds of audiences). ${ }^{44}$ The very idea of formal oratory, of the extended uninterrupted speech which Cicero's speeches preserve, requires critique. In reality, orators needed to earn their audience, and keep on earning it, by offering speech which was important enough and interesting enough to hold its attention, and in many cases its presence. They faced interruptions, and they needed to engage with what their audience said and did. These demands held true across what is in other respects a deep generic divide between forensic and deliberative oratory at Rome. Public life in Rome involved constant scrutiny by the people or by those to whom the people's responsibilities were delegated; that was the case even for men who were never prosecuted and thus managed to avoid the most intense and serious form of scrutiny offered by a quaestio.

The theatrical metaphor is an enticing one in attempting to understand Roman oratory, particularly forensic oratory. It is a metaphor that the Romans themselves used, fully aware that oratory involved performance and that the links between dramatic and forensic delivery could be close. But caution is needed, to avoid importing misleading analogies along with useful ones. Roman oratory was never more than partially scripted. It is as though the Roman orator entered the stage with his own part prepared and memorised, but with less than total confidence in what his co-performers might say, the uneasy consciousness that at any moment he might be entirely upstaged by a member of the audience, and the prospect of an empty theatre if he failed to deliver. ${ }^{45}$

\footnotetext{
${ }^{43}$ Steel (2013b) 151-9.

${ }^{44}$ Also: Morstein-Marx (2004) 119-59 on the populus. Senators could choose where they sat during meetings of the Senate.

${ }^{45}$ Perhaps not coincidentally, the Republican theatre was another place where vigorous audience responses was to be expected, as well as an alertness to the political significance - even if coincidental - of what was said.
} 